his aim. $\mathrm{He}$ became Manson's most faithful lieutenant and admirer; to him it was a pious task to defend Manson's reputation and to aid in preserving his memory, for, apart from all his discoveries and his greatness, he considered that Manson was the embodiment of the Hippocratic tradition. Henceforward he became the first teacher of medical entomology in the School of Tropical Medicine, and he added greatly to his reputation by the publication of his text-book, "Entomology for Medical Officers", 1912, which reached its second edition in 1920. This work was written in response to requests from students in his own School, and whilst directing its attention principally to the arthropods concerned in the dissemination of disease, it almost became an outline of zoology.

To thousands of post-graduate students of all nationalities, in his charming and unpretentious way, Alcock became guide, philosopher, and friend. Soon he became responsible for the foundation and establishment of the entomological collections of the School, and for the collection of poisonous snakes and other reptiles; in fact, the whole zoological fauna that make up the science of tropical medicine. $\mathrm{He}$ organised the Tropical Diseases Library of the School, and from 1912 onwards actively participated with Dr. A. G. Bagshawe in reviewing for the Tropical Diseases Bulletin, becoming the assistant director of the Bureau in 1921. He was very gratified in being elected in 1920 to the professorship of medical zoology in the University of London. His reviews of medical zoology, as indeed every letter and article he wrote, were characterised by a charming scholastic style, embroidered with a wealth of literary and classical allusions, which could scarcely be surpassed, and gave his work an air of great distinction.

Then came the War, and in his endeavours to serve his country, Alcock found himself appointed as surgeon to an Indian hospital at Brighton, but he found himself 'at sea' when armed with a scalpel, and instead devoted himself to instructing R.A.M.C. officers, proceeding overseas, in the elements of tropical medicine. The War being over, he returned to his active teaching, and in the following years he collaborated with Dr. P. Manson-Bahr in "The Life and Work of Sir Patrick Manson", which was published in 1927. He was thus afforded an opportunity of making clear the everlasting truth of medical biology as evidenced by the life story of Manson.

Alcock retired from active teaching in 1924, and had been living in seclusion at Belvedere in Kent, but in no wise did his zeal for his favourite subject abate.

It is scarcely necessary to enlarge further on his character-that of the true naturalist, and man of science, and a lover of his fellow creatures -in fact, a friend of all mankind. It was a common experience for a stranger on seeking his road in far away Belvedere to Alcock's house, to inquire the way of some whistling schoolboy, and to receive as an astonished reply, "Oh, that's where Col. Alcock lives; he is a great pal of mine." It is appropriate to quote his favourite lines :

"Nature is made better by no mean,

But nature makes that mean; so, over that art

Which you say adds to nature, is an art,

That nature makes-The art itself is nature."

His philosophy of life, like that of old Pittacus, of Mitylene, was: "The greatest blessing a man can enjoy is the power of doing good." So, when he is gone, we realise that the era of the pioneers of tropical medicine is closed.

Alcock was an LL.D. of the University of Aberdeen, and a corresponding member of the Zoological Societies of London and of the Netherlands, and also of the California Academy of Sciences.

\section{Dr. John Belling}

Dr. John Bellina, elder son of the late John Belling, inspector of Army Schools, who died on February 28 in San Francisco, was born at Aldershot, England, on October 7, 1866. He taught in various schools, attending lectures meanwhile at London and Birmingham, and obtained a London B.Sc. (Hons.). In later life he was given the honorary degree of Doctor of Science by the University of Maine in 1922. He lectured in the Horticultural College at Swanley, England; and later at Llanidloes, Wales, in 1900-1. Shortly after this he went to the British West Indies where he became investigator in the Department of Agriculture. In 1907 he went to the Florida Experiment Station as assistant botanist and carried out important researches there on hybrid beans.

Shortly after the War, Belling went to the Carnegie Institution of Washington as cytologist in the Department of Genetics, and was associated with Dr. A. F. Blakeslee in the investigation of the chromosomes of Datura. Here his genius in microscopy and his philosophical insight opened up a new field in the study of the behaviour of chromosomes and in the interchange of segments between non-homologous chromosomes. Belling was subject to periods of depression during which he did some of his most brilliant work. Believing that it was important for him to have a change of scene, he was transferred by the Institution to Berkeley, California, where he worked in a corner of Prof. E. B. Babcock's laboratory, continuing his fundamental researches on the structure of chromosomes in hyacinths and various lilies. In these investigations, under superlative technique, he believed he was able to see structures, which on account of their number and size, he identified with genes.

Belling was the author of a book on the use of the microscope, which has been eminently successful. He had also made considerable progress with a work on the study of the chromosomes. 
After the Sixth International Congress of Genetics, held in Ithaca last summer, a number of foreign delegates travelled to Berkeley to examine Belling's preparations showing the structure of the chromosomes, and to discuss with him his interpretations of them. He was also the author of a small book of verse, "The Life-World. Poems of Science" (published by the Margaret Mary Morgan Co., 619, California Street, San Francisco). It contains sixty poems concerning scientific (chiefly genetic) phenomena and also three others, the last of which, "Elegy", is of exceptional beauty.

Belling married Miss Hannah Sewall, who died in 1926 without issue. $\mathrm{He}$ is survived by a brother, James Belling, residing in the Cheltenham district, also by a sister, Miss Annie Belling.

\section{Prof. E. C. Starks}

WITH the passing at a comparatively early age of Prof. Edwin C. Starks, American ichthyological science has suffered yet another grievous loss, following, as it does, close upon the deaths of David Starr Jordan, Charles H, Gilbert, Carl H. Eigenmann and Barton Warren Evermann. Thus, within a comparatively few years the five zoologists, who, with Theodore N. Gill (1837-1914), may be said to have dominated the study of fishes in the United States during the last half century, have died.

Prof. Starks was born at Baraboo, Wisconsin, on January 25, 1867, studied at Stanford University from 1893 until 1897, and was then appointed assistant to the United States Biological Survey. From 1899 until 1901 he held the position of curator and assistant professor of zoology at Washington (Seattle). In 1901 he returned to Stanford University, being appointed curator in 1901, assistant professor in 1908 and associate professor in 1927.

A list of Starks's published works on fishes, including those in which he collaborated with Jordan, Gilbert and others, would contain some seventy or more titles. Many of these were of a systematic nature, and included the results of an ichthyological survey about the San Juan Islands, Washington, the fishes of Panama Bay (with Gilbert), and the fishes of Puget Sound (with Jordan). In collaboration with Jordan he was responsible for an important series of revisions and monographs of Japanese fishes published between 1901 and 1906. By far the most valuable of his contributions to ichthyology, however, were the series of papers dealing with the osteology and affinities of various groups of bony fishes. These papers, with their careful descriptions and well-drawn illustrations, furnish a monument of accurate and painstaking research, and are invaluable to students of fish taxonomy.

J. R. N.

We regret to announce the following deaths :

Prof. E. W. Hobson, F.R.S., formerly Sadleirian professor of pure mathematics in the University of Cambridge, on April 18, aged seventy-six years.

Sir Edward Rigg, C.B., C.V.O., who was appointed assistant assayer in the Royal Mint in 1873 and was superintendent of the Operative Department from 1898 until 1918, on April 14, aged eighty-three years.

\section{News and Views}

\section{Rubber Industry Bill}

IN the House of Commons on April 11, Mr. H. Williams asked the president of the Board of Trade whether he was aware that the Research Association of British Rubber Manufacturers had discharged many of its staff and suspended research work for lack of funds. (This matter was referred to in a leading article in our issue of February 11.) $\mathrm{Mr}$. Williams asked further whether, in the circumstances, facilities would be given for further progress of the Rubber Industry Bill. Mr. Runciman stated that he was aware of the situation. $\mathrm{He}$ said: "The Government recognise that it is desirable that the work of this Association should continue and have decided to give an opportunity for further discussion in Parliament of the Rubber Industry Bill." Owing to pressure of business in the House of Commons, it is proposed to introduce the Bill at an early date in the House of Lords.

\section{Improvement of Beef Cattle in Australia}

Ir, as predicted by Dr. J. B. Orr, Australia is to become "the stock farm of the Empire", one of its urgent needs is the improvement of the beef cattle breeds in the northern tropical parts of Queensland, North Australia and Western Australia. The handicaps to British breeds are sparse fodder and prevalence of ticks and tick fever. The success reported to have followed the introduction of Brahman (Zebu) strains into herds in poorly grassed, tick-infested territories bordering on the Gulf of Mexico induced the Australian Council for Scientific and Industrial Research in 1931 to make a close investigation of the actual position. As a result, it has for some time strongly advocated experimental breeding in Australia to evolve a suitable cross for the north between British and Brahman cattle. Lack of funds prevented immediate action, but four pastoral companies have now made sufficient money available to ensure a thorough test of the possibilities of the cross. An officer of the Council is in the United States selecting suitable animals (probably eight bulls and two cows) which will be shipped to Australia and, after compliance with exacting quarantine conditions, will be divided amongst the properties of the companies, which at present carry chiefly shorthorns and Herefords. All breeding and culling will be under the sole supervision and control of the 